\title{
Hei, meitä hallitaan
}

Peter Miller ja Nikolas Rose: Näin meitä hallitaan.

Suom. Risto Suikkanen. Vastapaino 2010. 345 s.

Katri Komulainen, Seija Keskitalo-Foley, Maija Korhonen ja

Sirpa Lappalainen (toim.) Yrittäjyyskasvatus hallintana.

Vastapaino 2010. 326 s.

HALLINTA eli käyttäytymisen ohjailu toivottuun suuntaan on valtiota ohentavissa länsimaissa korvannut keskitettyä hallintoa. Toisin kuin hallinto (government), hallinta (governance) perustuu vapaaseen tahtoon ja yksilöiden itsetoteutukseen. Kyse on säännellystä vapaudesta, jossa ihmisiä yllytetään tai vaaditaan vertaamaan saavutuksiaan siihen, mitä he voisivat olla. Miller ja Rose eivät kritisoi lumevapautta jonkin todellisemman vapauden nimissä, vaan he pyrkivät osoittamaan, miten uudet vallan muodot perustuvat vapauden ennakko-oletukselle. Hallinnan muodoista Miller ja Rose tarkastelevat taloutta, politiikkaa, yhteisöjä, kulutusta ja terapeuttista auktoriteettia. Kiinnostuksen kohteina ovat foucault'laisittain "alamaistamiskäytännöt", vallan muodot ja totuuksien tuottamisen tavat.

Vallan muodot tulevat etäältä ja suuntautuivat yhtä lailla yksilöihin kuin yhteisöihin. Valta suuntautuu henkilökohtaisille alueille, kuten perheisiin, ja toisaalta persoonattomille alueille, kuten aikatauluihin, työsuunnitelmiin tai laskentajärjestelmiin. Hallinnan analyysissa tarkastellaan epäsuoria tapoja, jotka linjaavat taloudellisen, yhteiskunnallisen ja henkilökohtaisen käyttäytymisen samansuuntaiseksi yhteiskunnallis-poliittisten tavoitteiden kanssa. Miller ja Rose ilmoittavat kiinnostuneensa enemmän mitenkysymyksestä kuin miksi-kysymyksestä. He haluavat keskittyä tapahtumien erityisyyteen, "tapahtumallistumiseen", ja ihmisten välisiin suhteisiin silloinkin, kun kiusaus olisi pikemminkin vedota ihmisen ominaislaatuun, historian lakeihin tai muunlaisiin tapahtumien väistämättömiin syihin.

\section{MILLOIN HALLINTA ON TARPEEN?}

Hallinta käy tarpeelliseksi, kun yksilöiden tai yhteisöjen toiminta on jonkun mielestä ongelmallista. Ongelmallisuuden määrittely ja muotoilu on kirjoittajien mukaan hidas prosessi, johon tarvitaan eri alojen asiantuntijoita, poliitikkoja, talousvaikuttajia, mediaa tai painostusryhmiä. Paikat, jossa toiminta on käynyt ongelmalliseksi, voivat olla moninaisia, kuten koti, koulu, katu, työpaikka tai ostoskeskus. Paikka on voitava muuntaa alueeksi, joka tarvitsee hallintaa. Väestön, kansantalouden, yrityksen, perheen, lapsen tai oman itsen hallinta tulee mahdolliseksi, kun hallittava alue esitetään käsitettävissä olevana kenttänä piirteineen, rajoineen ja kytkeytymisineen.

Erityisesti kirjoittajia kiinnostaa vaihe, jolloin ongelmallisuus nousee ihmis- ja yhteiskuntatieteisiin tukeutuvien asiantuntijoiden analysoitavaksi. Tässä vaiheessa yleensä osoitetaan jokin yksilöllisen tai kollektiivisen käyttäytymisen tapa syypääksi kuvattuun ongelmaan. Käyttäytymistä saatetaan pitää vaarallisena ja vahingollisena, tai sitten ihanneolotilaan verraten tehottomana ja riittämättömänä.

Asiantuntijakielen arvot ja normit näyttävät pakottavilta, koska niihin näyttää sisältyvän pyyteetön totuus ja lupaus ongelmien ratkaisusta. Kieli voi vedota yhtä lailla poliitikkoihin, virkamiehiin, kasvattajiin ja muihin tehokasta ratkaisua toivoviin, myös niihin, jotka kokevat tarvitsevansa asiantuntijoiden opastusta.

Kirjoittajat tarkastelevat hallintatavan kahta puolta, rationaliteettia ja teknologiaa. Rationaliteetit ovat ajattelutyylejä ja tapoja tehdä todellisuus ajateltavaksi, laskelmoitavaksi ja ohjelmoitavaksi. Rationaliteeteille on löydettävä toteutumisen tapoja, teknologioita. Ne puolestaan koostuvat ihmisistä, tekniikoista ja instituutioista eli käyttäytymisen ohjausvälineistä, jotka voivat ohjailla ihmisiä pitki- 


\section{"ERITYISEN SELKË̈STI OMAEHTOINEN}

\section{ITSETOTEUTUS SEK ̈̈ KANSALAISUUDEN JA}

TUOTTAVUUDEN VELVOITTEET YHDISTYVÄT

ELINIK ̈̈ISEN OPPIMISEN NORMEISSA."

enkin etäisyyden takaa. "Hallintamentaliteetit" (Foucault'n uudissana gouvernementalité) ovat sekä mentaliteetteja että teknologioita - sekä ajattelutapoja että asioihin puuttumisen välineitä.

\section{ITSETOTEUTUS}

\section{KANSALAISVELVOLLISUUTENA}

1900-luvun alkupuolen politiikan rationaliteetin muodot loivat kansalaisen, jonka valtuudet ja velvollisuudet ilmaistiin sosiaalisen vastuun ja kollektiivisen solidaarisuuden kielellä. Yksilöt liitettiin yhteiskuntaan vastavuoroisella sopimuksella. Hyvinvointivaltion uudistusten kulta-aikaa oli sodanjälkeinen 30 vuoden jakso, joka päättyi uusliberalismin valtakauteen ja kansalaisuuden määrittelyyn rationaalisia valintoja tekevänä yksilönä, kuluttajana. Millerin ja Rosen mukaan nyt myös hallinnon ohjelmia arvioidaan sen perusteella, miten niissä toteutuu valintojen mahdollisuus.

Taylorismin jälkeen työntekijä käsitteellistettiin yksilöksi, jota on jatkuvasti arvioitava, erotettava muista ja hallittava yksilöllisten erojen perusteella. Työttömyys määritellään asianomaisen puutteelliseksi osaamiseksi ja markkinointitaidoiksi. Itsetoteutus, itsensä esittämisen taidot, itseoh- jautuvuus ja itsensä johtaminen ovat sekä henkilökohtaisesti että taloudellisesti toivottavia päämääriä. Erityisen selkeästi omaehtoinen itsetoteutus sekä kansalaisuuden ja tuottavuuden velvoitteet yhdistyvät elinikäisen oppimisen normissa.

Uusi julkisjohtaminen (NPM) on siirtänyt budjetointivaltaa paikallisille palvelun toteuttajille, mutta vastineeksi ihmisasiantuntijoiden edellytetään puhuvan kustannusten ja hyötyjen kielellä oman asiantuntijakielensä sijasta. Toiminnan siirtäminen numeraalisen arvioinnin kohteeksi muuntaa toimintaa, ja tekniset vaatimukset korvaavat asiantuntijatyön sisäisen logiikan.

Kuluttajakansalaiset maksimoivat elämänlaatuaan tavaroiden avulla ja rakentavat omaa elämäntapaansa. Markkinatutkimuksen ja mainonnan asiantuntijat tuovat tiedon, jonka avulla politiikan, talouden ja kansalaisten toiveet ja pyrkimykset voidaan muuttaa toisikseen. Tavistock Institute of Human Relations'in 1950-60-lukujen toimintaa kuvataan esimerkkinä psykologisen ja psykoanalyyttisen tiedon hyödyntämisestä markkinoinnissa. Kuvaus perustuu laajoihin mutta vähän tunnettuihin arkistoaineistoihin.
Millerin ja Rosen kirjoittamistapa on brittiläisittäin coolia. Voisi kuvitella, että saksalainen kirjoittaja esittäisi samasta aihepiristä perusteellista sivilisaatiokritiikkiä, ehkä myös utopioita, ja ranskalainen ironisoisi kohdettaan ja kieputtelisi retorisia tehokeinoja, mutta esittäisi yhtä lailla purevaa kritiikkiä. Millerin ja Rosen kuvaus on puolestaan kuivahkoa ja etäännytettyä, asiat ikään kuin puhuvat puolestaan. Brittiläistä perua lienee myös lukijaystävällinen tapa kertoa selkeästi, millainen näkökulma kulloinkin on valittu ja millainen on suljettu pois. Lukijaa voi muuten ansiokkaassa - ja hyvin suomennetussa - teoksessa jäädä askarruttamaan, missä ovat vapaasti valitsevien hallinnan kohteiden mahdollisuudet valita ja toimia toisin.

\section{YRITTÄJÄMINÄ}

Sisäisen yrittäjyyden johtamisoppi merkitsi alun perin sitä, että organisaatioissa ei ole enää työyhteisöjä tai velvollisuuksien ja oikeuksien mukaan suuntautuvia työntekijöitä, vaan hyötyään maksimoivia ja rationaalisia valintoja tekeviä yrittäjäyksilöitä. Sanan historia on kuitenkin unohdettu, ja uuspuheessa sisäinen yrittäjyys ja yrittäjämäinen asenne merkit- 
see vapautta, tehokkuutta, innovatiivisuutta ja ylipäänsä kaikkea hyvää "tehottoman" julkisen hallinnon vastakohtana.

Katri Komulaisen ym. toimittamassa artikkelikokoelmassa keskitytään suuren suosion saaneeseen yrittäjyyskasvatukseen hallinnan muotona. Yksilöistä halutaan kasvattaa yrittäjämäisiä kansalaisia eli aktiivisia ja itsenäisiä toimijoita, jotka ovat itse vastuussa omasta työllisyydestään ja hyvinvoinnistaan. Vuonna 2004 käynnistettiin yrittäjyyskasvatuksen toimenpideohjelma, ja yrittäjyyskasvatus on sittemmin levinnyt esiopetuksesta yliopistoihin. Yrittäjyys kuuluu myös EU-komission määrittämiin ”EUkansalaisen perustaitoihin".

Tavoitteeksi asetettu yrittäjäminuus ei tarkoita vain sisäistä tai ulkoista yrittäjää, vaan moraalista ihannetta hyvästä ihmisestä ja hyvästä elämästä. Hyvinvointiyhteiskunnan oikeuksien ja velvollisuuksien mukaan suunnistavan kansalaisen sijasta kilpailuyhteiskunnan kansalainen arvioi riskejä ja investoi itseensä yritteliäisyyden moraalisten periaatteiden mukaisesti. Vallan muoto toimii " ahdistuksen ja riittämättömyyden tunteiden kautta" (Kristiina Brunilan ja Sari Mononen-Batista Costan artikkeli).
Samalla työttömyys, köyhyys tai muu kyvyttömyys elättää itsensä muuttuvat moraalittomuudeksi. Tällaisia henkilöitä ei sisällytetä vapaan yksilöllisyyden puheeseen, vaan heitä hallinnoidaan perinteisin keinoin. Suomalaisista sosiaalityöntekijöistä jopa viidennes uskoo, että köyhyys on omaa syytä, kun muiden Pohjoismaiden kollegoista tätä mieltä on vain muutama prosentti (Yhteiskuntapolitiikka-lehti 6/10).

Kirjoittajien aiheellisen kritiikin mukaan yrittäjäminä eli individualistinen yksilö on hallinnan perusteluna ja kohteena kovin ohut rakennelma. Itsenäisyyttä ja yksilöllisiä saavutuksia korostava, rationaalisia valintoja tekevä minuus on länsimaisen valkoisen keskiluokkaisen kaupunkilaismiehen projekti - tuskin kaikkien heidänkään. Paitsi hallintakäytäntöjen oikeutuspuheessa myös hallintaa kritisoivissa teorioissa yksilöllistyminen nähdään usein yleisenä ja abstraktina, eikä sen suhdetta sosiaalisiin eroihin kuten luokkaan tai sukupuoleen kovinkaan tarkoin eritellä.

Suomen akatemian Yrittäjäminä-tutkimushanketta esittelevä teos tuo tarpeellisen lisän kotimaiseen hallinnan tutkimukseen. Selkeän rajauksensa ansiosta artikke- likokoelma pysyy hyvin koossa. Koska nykyiset hallinnan teoriat ovat paljolti Michel Foucault'n valta-analytiikan inspiroimia, monille kirjan artikkeleille olisi ollut eduksi hänen ajattelunsa perusteellisempi käsittely. Nyt kaikkien 14 kirjoittajan yhteisessä lähdeluettelossa on vain Foucault'n luetuin teos Tarkkailla ja rangaista sekä yksi lyhyehkö artikkeli.

\section{Jussi Onnismaa}

dosentti, työnohjaajien kouluttaja, Koulutus- ja kehittämiskeskus Palmenia, Helsingin yliopisto 